\title{
ANALISA MODEL ARSITEKTUR POHON DI KAWASAN TAMAN KOTA KABUPATEN BANYUWANGI
}

\author{
N. Nurchayati ${ }^{1)}$, Fuad Ardiyansyah ${ }^{1)}$ \\ ${ }^{1}$ Program Studi Bilogi, Fakultas Matematika dan Ilmu Pengetahuan Alam, \\ Universitas PGRI Banyuwangi \\ email: nurchayati@unibabwi.ac.id
}

\begin{abstract}
Abstrak
Penelitian analisa model arsitektur ini dilakukan di taman kota Kabupaten Banyuwangi, tepatnya di taman kota Sayu Wiwit, Sritanjung dan Blambangan. Tujuannya untuk mengetahui model-model arsitektur pohon yang ditanam di kawasan taman kota, sehingga kedepannya dapan melakukan prediksi tanaman yang tepat untuk kebutuhan paruparu kota. Penelitian ini dilakukan dengan mengamati pola percabangan pohon dan mendeskripsikannya ke dalam golongan model arsitekturnya. Arsitektur dari pertumbuhan tanaman adalah gambaran morfologi pada suatu fase tertentu dari rangkaian pertumbuhan pohon. Arsitektektur pohon memiliki sifat yang dinamis, karena setiap tumbuhan akan mengalami pertumbuhan dan perkembangan. Model arsitektur pohon dapat digunakan sebagai data tambahan dalam membedakan antar jenis pohon. Hasil dari proses penelitian menunjukkan bahwa terdapat 21 spesies pohon yang digunakan sebagai peneduh. Semua jenis yang ditemukan tersebut tergabung dalam 13 Famili. Masing-masing tanaman menunjukkan model arsitektur troll, aubreville, corner, raux, massart, rauh, campagnat, kwan koriba.
\end{abstract}

\section{Kata kunci: Model, arsitektur pohon, taman kota, percabangan}

\begin{abstract}
This architectural model analysis research was conducted in the city park of Banyuwangi Regency, precisely in the city park of Sayu Wiwit,Sritanjung and Blambangan. The aim of this research is to find out the architectural models of tree in park areas. So that in the future they can make prediction of the right plants that needs of the city's lungs. This research was conducted by observing the branching pattern of tree and describing them into architectural models. The architectural of plant growth is a morphological description at a certain phase of tree growth series. Tree architecture has dynamic nature, because every plant will experience groeth and development. The tree architecture model can be used as additional data in distinguishing between tree types. The result of the research process showed that there were 21 species of tree used as shade. All the species found belong 13 families. Each plant shows an srchitectural ,odel of troll, aubreville, corner, raux, massart, rauh, campagnat, and kwan koriba.
\end{abstract}

Keywords: Model, tree architecture, city park, branching 


\section{PENDAHULUAN}

Kondisi lingkungan saat ini mengalami banyak prubahan iklim. Tentunya kondisi ini banyak menimbulkan perubahan alam. Salah satu contoh nyata adalah musim kemarau yang semakin panjang serta musim penghujan yang relatif pendek.

Kondisi seperti ini jika berlangsung terus menerus maka akan menyebabkan terjadinya perubahan iklim. Kondisi perubahan iklim dapat terlihat pada peristiwa kekeringan yang panjang, adanya perubahan suhu pada permukaan laut, fenomena banjir dan tanah longsor, terjadinya krisis pangan, dan berkurangnya sumber mata air yang bersih (Hairiah K, Rahayu S. 2007).

Ragam upaya bisa dilakukan dalam rangka untuk mengatasi dampak dari perubahan iklim. Salah satunya adalah diterapkannya pemanfaatan pepohonan untuk mengurangi emisi gas rumah kaca. Salah satu tempat yang potensial menjadi lokasi penanaman pohon adalah taman kota (Putri AHN, dkk. 2015). Taman kota merupakan ruang terbuka hijau yang berupa taman untuk umum dan dikelola oleh pemerintah daerah sehingga bisa dipergunakan oleh masyarakat umum untuk kepentingan refreshing. Berdasarkan fisiknya taman kota termasuk wilayah yang bersifat non alami, karena merupakan bagian yang direncanakan sedemikian rupa sebagai bagian perencanaan kota. Kekhasan dari taman kota adalah lokasinya yang mudah diakses, tertata dengan rapi, sehingga pengguna merasa nyaman memanfaatkannya atau berada di dalamnya.

Taman kota di wilayah Kabupaten Banyuwangi ada tiga, diantaranya Taman Sritanjung, Blambangan dan Sayu Wiwit. Masing-masing taman tersebut di desain dengan konsep indah dan klasik. Taman kota selain sebagai tempat umum bagi masyarakat juga berperan sebagai paru-paru kota, sehingga seharusnya setiap tanaman yang ditanam memiliki karakteristik tertentu. Beberapa karakteristik tanaman yang ditanam di taman kota antara lain meliputi : 1) mempu menyerap gas CO2 dan zat timbale yang berlebih; 2) menghasilkan oksigen yang optimal; 3) tinggi 
pohon lebih dari tiga meter, tetapi tidak lebih dari dari 12 meter; 4) kerimbunan daunnya yang menutup sinar matahari; 5) tajuknya bisa menutupi area yang luas; 6) perawatannya mudah; 7) ukuran ranting tidak terlalu besar dan tidak mudah patah; 8) akar menancap kuat sehingga tidak mudah tumbang dan tidak merusak bangunan. Harapannya dengan keberadaan tanaman di taman kota iklim dapat diperbaiki secara dalam lingkup kecil. Selain itu keberadaan taman kota dapat menambah nilai keindahan dan menciptakan keseimbangan dalam lingkungan fisik kota. Keanekeragaman tanaman dalam taman kota harapannya bisa mendukung pelestarian keanekaragaman hayati Indonesia (Handoko, P. 2007).

Setiap tanaman yang ditanam pada taman kota memiliki morfologi percabangan yang berbeda-beda. Percabangan pohon merupakan hasil dari diferensiasi morfologi pada sumbu vegetative dan dapat membentuk pola arsitektur khusus untuk kepentingan klasifikasi untuk taksonomi dan interpretasi suatu bentuk tumbuhan. Berbagai pola percabangan tersebut dapat dibedakan menjadi tiga macam, yaitu pola percabangan monopodium, simpodium dan dikotom (Tjitrosoepomo, 2007).

Suatu bentuk pola percabangan tumbuhan dapat membentuk model arsitektur tumbuhan. Arsitektur dari pertumbuhan tumbuhan ini adalah gambaran morfologi pada suatu fase tertentu dari rangkaian pertumbuhan pohon. Arsitektektur pohon memiliki sifat yang dinamis, karena setiap tumbuhan akan mengalami pertumbuhan dan perkembangan. Model arsitektur pohon dapat digunakan sebagai data tambahan dalam membedakan antar jenis pohon (Hasanudi, 2013).

Menurut Ekowati G, dkk, 2017, model arsitektur pohon berdasarkan pola percabangan tersebut sangat menentukan letak duduk daun dan kanopi suatu pohon. Pohon dengan kanopi yang luas maka akan memiliki biomassa yang besar pula sehingga akan memiliki potensi menyerap karbon lebih besar. Melalui penelitian ini akan dilakukan analisa terhadap model arsitektur pohon yang ada di kawasan taman kota dan menghubungkan dengan luas biomassanya. Sehingga akan diketahui potensi 
penyerapan karbon dari masing-masing model. Harapannya hasil penelitian ini akan menjadi referensi dalam penentuan jenis tanaman yang tepat untuk mengisi kawasan RTH taman kota khususnya kabupaten Banyuwangi. Sehingga setiap tanaman yang dipilih, selain memenuhi nilai estetika juga benar-benar dapat menjadi solusi dalam mengatasi perubahan iklim yang terus terjadi dewasa ini.

\section{METODE PENELITIAN}

Penelitian tentang model arsitektur pohon dan potensi serapan karbonnya ini dilaksanakan di kawasan Taman Kota di Kabupaten Banyuwangi. Taman kota yang dijadikan lokasi penelitian ini difokuskan pada tiga lokasi, yaitu taman kota Sritanjung, Blambangan dan Sayu Wiwit Banyuwangi. Ketiga lokasi tersebut dipilih karena ketiganya adalah taman kota popular yang banyak dikunjungi oleh masyarakat kabupaten Banyuwangi. Pengamatan lebih lanjut dari hasil dokumentasi dilakukan di Laboratorium Biologi Fakultas MIPA Universitas PGRI Banyuwangi. Penelitian ini dilakukan mulai bulan Mei sampai September 2020.

Berbagai alat yang digunakan dalam penelitian ini adalah sebagai berikut: kameraa (untuk proses dokumentasi pohon), seperangkat alat tulis (untuk melakukan dokumentasi secara tertulis), penggaris dan meteran pita (untuk mengukur percabangan tanaman), buku identifikasi model arsitektur pohon karangan $F$. Halle \& .A.A.Oldeman, yaitu: An Essay On The Architecture and Dynamics of Growth of Tropical Trees.

Tahapan penelitian yang dilakukan meliputi beberapan tahapan, diantaranya adalah: 1) Eksplorasi dengan metode jelajah; 2) Proses pengamatan model arsitektur percabangan dengan pengamatan secara langsung dan melakukan aktivitas pemotretan terhadap tumbuhan yang akan diamati; 3) identifikasi tumbuhan dengan Flora of Java, Identification of tropical Woody Plants in The Absence of Flower. 


\section{HASIL DAN PEMBAHASAN}

\subsection{Model arsitektur pohon dan deskripsi beberapa pohon di kawasan Taman Kota Kabupaten Banyuwangi}

Hasil pengamatan percabangan pohon dikawasan Taman Kota Kabupaten Banyuwangi yang meliputi Taman Sritanjung, Blambangan, dan Sayu Wiwit menunjukkan ada 21 spesies pohon yang digunakan sebagai peneduh. Semua jenis yang ditemukan tersebut tergabung dalam 13 Famili. Masing-masing tanaman menunjukkan model arsitektur troll, aubreville, corner, attim, raux, massart, rauh, campagnat, kwan koriba. Berikut ini adalah daftar jenis pohon dan model arsitekturnya di kawasan taman kota Banyuwangi :

Tabel 1. Model Arsitektur Pohon di Kawasan Taman Kota Kabupaten Banyuwangi

\begin{tabular}{cllll} 
No & \multicolumn{1}{c}{ Famili } & \multicolumn{1}{c}{ Spesies } & \multicolumn{1}{c}{$\begin{array}{c}\text { Nama } \\
\text { Daerah / Indonesi } \\
\text { a }\end{array}$} & $\begin{array}{c}\text { Model } \\
\text { Arsitektur } \\
\text { Pohon }\end{array}$ \\
\hline 1 & Mimosoideae & Samanea saman & Saman/Trembesi & Troll \\
\hline 2 & Combretaceae & Terminalia mantaly & Ketapang kencana & Aubreville \\
\hline 3 & Arecaceae & Elaeis guineensis & Sawit & Corner \\
\hline 4 & Areacaceae & Saribus rotundifolia & Palem sadeng & Corner \\
\hline 5 & Arecaceae & Dypsis lutescens & Palem Kuning & Corner \\
\hline 6 & Arecaceae & Trachycarpus sp. & Palem kipas & Corner \\
\hline 7 & Arecaceae & Roystonea regia & Palem putri & Corner \\
\hline 8 & Sapotaceae & Mimusop elengi & Tanjung & Attim \\
\hline 9 & Sapotaceae & Manilkara kauki & Sawo Kecik & Aubreville \\
\hline 10 & Annonaceae & Polyalthia longifolia & Glodokan tiang & Raux \\
\hline 11 & Myrtaceae & Syzygium malaccense & Jambu bol & Massart \\
\hline 12 & Fabaceae & Pithecelobium dulce & Asam Belanda & Rauh \\
\hline 13 & Fabaceae & Erythrina crista-galli & Dadap merah & Troll \\
\hline 14 & Moraceae & Artocarpus heterophyllus & Nangka & Rauh \\
\hline 15 & Moraceae & Ficus benjamina & Beringin & Rauh \\
\hline 16 & Moraceae & Ficus benghalensis & Beringin india & Rauh \\
\hline 17 & Caesalpiniaceae & Caesalpinia pulcherrima & Kembang merak & Campagnat \\
\hline 18 & Clusiaceae & Clusia rosea & Pohon tanda tangan & Rauh \\
\hline 19 & Apocynaceae & Alastonia scholaris & Pule & Prevost/ \\
& & & & Kwan Koriba \\
\hline 20 & Casuarinaceae & Casuarina equisetifolia & Cemara udang & Rauh \\
\hline 21 & Cupressaceae & Platycladus orientalis & Cemara kipas & Raux \\
\hline & & & & \\
\hline
\end{tabular}


Berikut adalah hasil dari deskripsi secara morfologi pohon yang dipergunakan untuk contoh model arsitektur pohon di kawasan taman kota Banyuwangi :

\section{Samanea saman (Trembesi)}

Tanaman saman atau trembesi batangnya berupa simpodium, dan daun yang cenderung berhadapan. Bentuk batang bulat, berwarna coklat dan permukaannya beralur. Pertumbuhannya memiliki arah tegak. Percabangan bersifat monopodial dengan sumbu pertama bersifat tumbuh ke arah atas dan sumbu ke sekian kalinya mulai mengalami differensiasi secara plagiatrop (tumbuh kearah samping) secara perlahan. Tanaman trembesi ini memiliki model arsitektur troll. Beberapa tanaman lain yang memiliki model arsitektur troll adalah pohon dadap merah (Erythrina crista-galli).

\section{Terminalia mantaly (Ketapang kencana)}

Tanaman Ketapang kencana memiliki penciri berupa batang yang simpodium. Kuncupnya yang paling ujung berhenti pertumbuhannya dan berdiferensiasi menjadi parenkim. Kuncup aksilarnya berkembang ke arah bawah, membentuk bagian yang disebut koulomner identik, tetapi pada perkembangannya mengalami perbedaan. Satu menjadi koulomner batang dan yang lain menjadi koulomner yang berupa cabang. Tanaman ketapang kencana ini memiliki model arsitektur aubreville.

\section{Elaeis guineensis (Sawit)}

Sawit adalah tanaman dengan satu meristem satu meristem, memiliki sifat monopodial dan perbungaan lateral inflourescence. Pohon tidak bercabang dengan tinggi batang bisa berukuran lebih dari $30 \mathrm{~m}$ dan diameternya bisa mencapai $40 \mathrm{~cm}$. Batang tegak dan berwarna abu-abu sampai berwarna agak coklat dengan tajukmekar. Tangkai daun dan rachis berwarna hijau. Bunga terdapat pada bagian pada bagian aksial. Tanaman sawit ini arsitekturnya memiliki model corner. 


\section{Manilkara kauki (Sawo kecik)}

Tanaman sawo kecik berhabitus pohon dengan batang memiliki tipe percabangan simpodial. Akan tetapi batang bagian bawahbersifat monopodial. Pertumbuhan tanaman ini ritmik dan cabang-cabangnya berkembang menjadi cabang simpodial yang bersifat plagiotropik Tinggi pohon memiliki kisaran 15-20 m. Daun berbentuk elips terbalik dengan panjang 5-12 $\mathrm{cm}$. Tanaman sawo kecik memiliki model arsitektur aubreville.

\section{Polyalthia longifolia (Glodokan tiang)}

Tanaman glodogan tiang nemiliki ciri batang yang monopodial dengan pola pertumbuhan ritmik serta membentuk pola percabangan orthotropic. Tampilannya seperti pyramid yang mengerucut. Daun berwarna hijau dengan tepi daun bergelombang. Akarnya mampu menembus tanah dan tidak berpotensi merusak bangunan sekitar. Tanaman glodogan tiang ini memiliki model arsitektur pohon raux.

\section{Syzygium malaccense (Jambu bol)}

Tanaman jambu bol memiliki batang berbentuk bulat yang tidak terlalu besar. Ketinggian tanaman berkisar sampai $15 \mathrm{~m}$. Percabangan rendah tetapi memiliki tajuk yang cukup rapat. Tekstur batang kasar. Daun tanaman merupakan daun tunggal dengan duduk daun opposite. Bentuk daun lonjong, besar, dan bersifat menjorong. Akar tanaman jambu bol berupa tunggang yang mampu menembus tanah hingga kedalaman 5 sampai $10 \mathrm{~m}$. Tanaman ini memeiliki tipe percabangan arsitektur dengan model massart.

\section{7. $\quad$ Ficus benjamina L. (Beringin)}

Tanaman beringin memiliki batang bulat dengan pertumbuhan tegak, permukaan yang kasar dan berwarna coklat kehitaman. Tanaman ini tipe percabangan batangnya monopodial dan cabang-cabang plagiotropik. Batang 
seringkali terdapat akar gantung. Daunnya merupakan daun tunggal dengan duduk daun yang saling berhadapan. Tanaman beringin memiliki model rauh.

\section{Caesalpinia pulcherrima (Kembang merak)}

Tanaman kembang merak memiliki habitus perdu. Ketinggiannya hanya berkisar 2 sampai $4 \mathrm{~m}$. Percabangannya lumayan banyak walupun diameternya tidak terlalu besar. Daun tanaman kembang merak merupakan daun majemuk menyirip ganda dua. Anak daunnya berbentuk ellips dengan ujung bulat, tepi rata. Tanaman ini memiliki model arsitektur pohon tipe campagnat.

\section{Alastonia scholaris (Pule)}

Tanaman pule memiliki batang lurus, bulat, dan tidak memiliki alur. Susunan daun terbentuk dalam suatu lingkaran yang memiliki 4-8 daun. Helai daun bagian atas berwarna hijau, sedangkan bagian yang bawah agak suram. Pangkal tangkai daunnya bagian dalam memiliki selaput yang menutupi kelenjar pada helaian daun. Tanaman pule ini memiliki tipe arsitektur percabangan model prevost atau kwan koriba

\subsection{Deskripsi model arsitektur beberapa pohon di kawasan Taman Kota Banyuwangi}

Model-model arsitektur pohon hutan terdiri atas 23 model untuk jenis-jenis pohon dan tumbuhan hutan lainnya dijumpai sebagai model pada pohon-pohon hutan di wilayah tropika. Arsitektur pohon tersebut merupakan abstraksi genetic dari suatu tanaman pada saat mengawali pertumbuhannya. Sehingga dikatakan bahwa bahwa arsitektur pohon bukanlah pola pertumbuhan, habitus maupun bentuk-bentuk tajuk atau kanopi. Arsitektur tersebut merupakan hasil finishing dari suatu pola pertumbuhan jaringan meristem apikal. Ukuran tanaman dan habitus dari suatu tanaman tidak dapat dijadikan faktor pembeda. Karena kalau ditinjau dari ukuran atau habitusnya, pohon dan tanaman herba bisa memiliki hasil akhir pertumbuhan 
yang sama. Berikut adalah deskripsi tumbuhan model arsitektur:

\section{Model Corner}

Salah satu tanaman yang termasuk model corner adalah palem. Model ini dicirikan dengan batang yang kokoh kuat, tinggi 10-30 m. Ujung tanaman tidak bercabang dan bersifat monopodial. Duduk daun spiralis dengan perbungaan influorescensia apical. Model corner yang terdapat pada taman kota adalah palem sadeng (Saribus rotundifolia), sawit (Elaeis guineensis), palem kuning (Dypsis lutescens), palem kipas (Trachycarpus sp.), dan palem putri (Roystonea regia). Contoh dari tumbuhan model arsitektur corner yang di Taman kota adalah seperti gambar berikut :
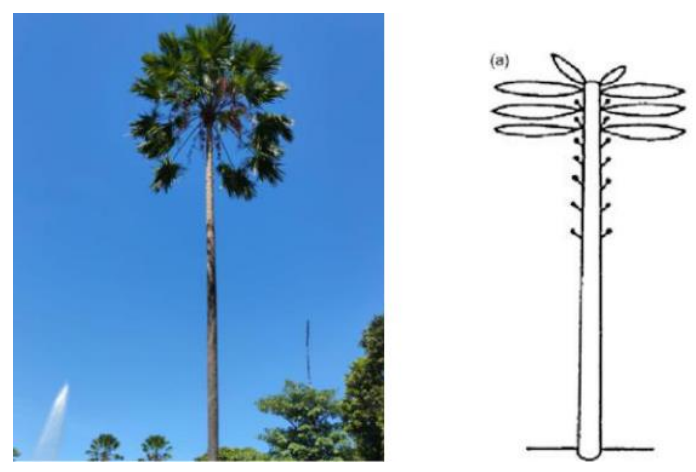

Gambar 1. Saribus rotundifolia
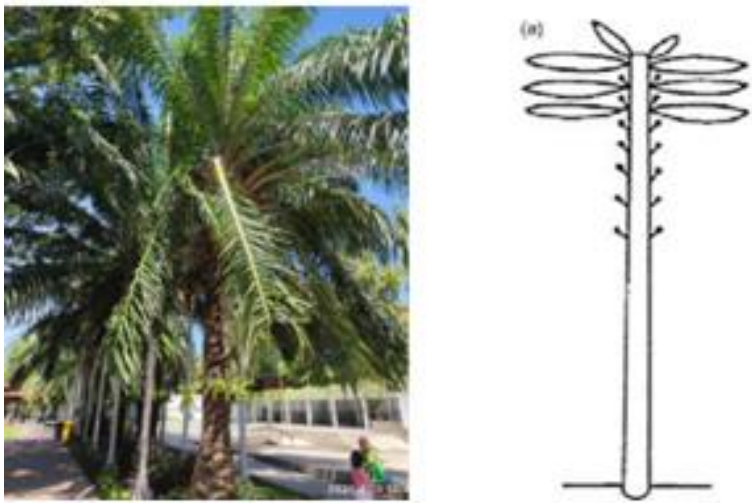

Gambar 2. Elaeis guineensis 


\section{Model Troll}

Model Troll memiliki ciri khas, yaitu adanya batang yang simpodial secara plagiotrop sejak dini. Pohon berbunga setelah dewasa, dan daun cenderung berhadapan. Pembentukan batang tegak terjadi setelah daun mulai habis berguguran. Contoh tumbuhan dengan model arsitektur ini di taman kota Banyuwangi adalah pada tanaman saman atau trembesi (Samanea saman) dan dadap merah (Erythrina crista-galli).
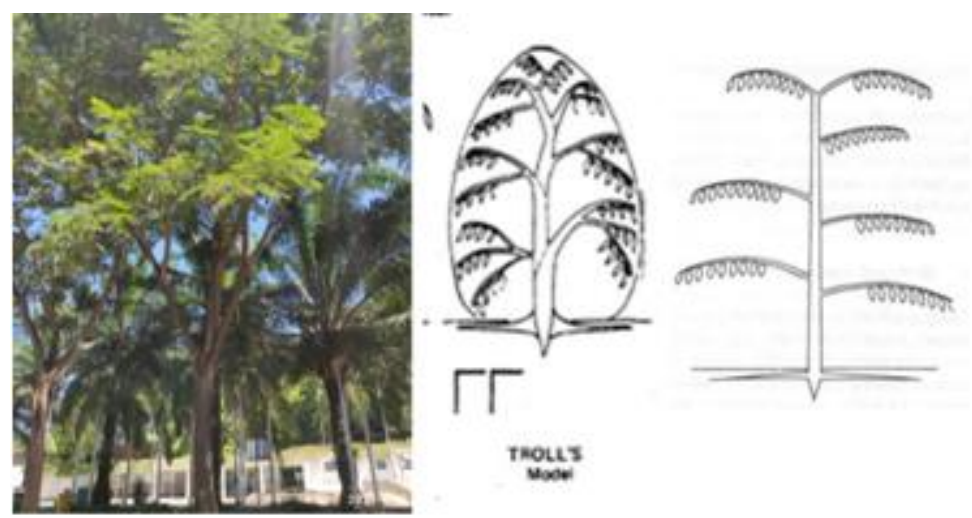

Gambar 3. Samanea saman

\section{Model Kwan Koriba}

Model arsitektur kwan koriba memiliki ciri khas yaitu batang yang simpodium. Kuncup terminal telah terhenti pertumbuhannya, karena jaringan meristem bagian ujung telah berdiferensiasi menjadi jaringan parenkim. Kuncup ketiaknya berkembang membentuk koulomner yang berbeda. Satu menjadi koulomner batang dan yang lain menjadi koulomner cabang. Tanaman di taman kota Banyuwangi yang memiliki model kwan koriba adalah pula (Alastonia scholaris). 

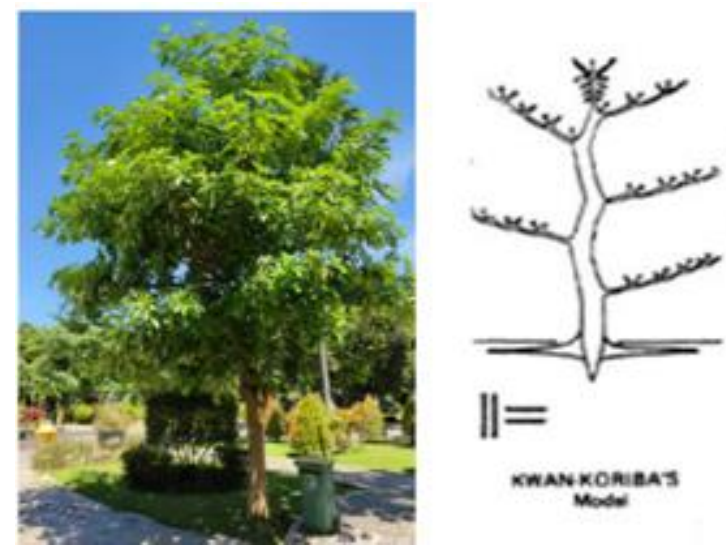

Gambar 4. Alastonia scholaris

\section{Model Aubreville}

Model Aubreville merupakan model arsitektur yang dicirikan dengan percabangan batang monopodial dan memiliki pertumbuhan yang bersifat ritmik. Masing-masing bagian cabangnya tumbuh secara plagiotopik dan letak perbungaan terdapat pada bagian lateral. Pohon yang memiliki model arsitektur aubreville di taman kota Banyuwangi adalah ketapang kencana (Terminalia mantaly) dan sawo kecik (Manilkara kauki).
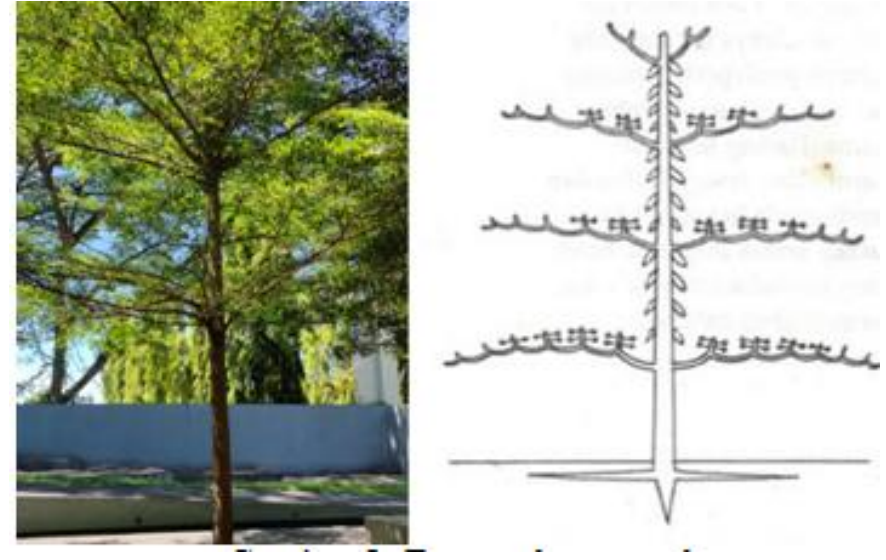

Gambar 5. Terminalia mantaly 


\section{Model Rauh}

Model arsitektur rauh bercirikan dengan percabangannya yang tersusun dari batang monopodial yang tumbuh secara ritmik. Kanopi berbentuk sepertii vas dengan bagian bawah kanopi sempit dan ke atas makin melebar. Perbungaan terletak lateral. Pertumbuhannya yang ritmis menyebabkan tanaman model ini seperti suatu karangan. Tanaman dengan model rauh di taman kota Banyuwangi meliputi pohon nangka (Artocarpus heterophyllus), beringin (Ficus benjamina), beringin india (Ficus benghalensis variegata), pohon tanda tangan (Clusia rosea), dan cemara udang (Casuarina equisetifolia).
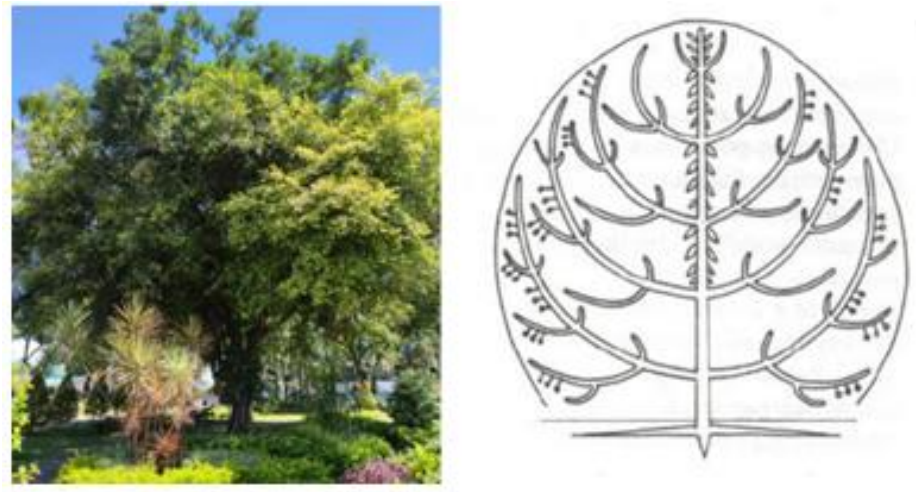

Gambar 6. Ficus benghalensis variegate

\section{Model Raux}

Model arsitektur raux adalah jenis arsitektur percabangan pohon dengan ciri batang bercabang poliaksial, dengan aksis vegetative tidak sama. Percabangan pada seluruh tanaman bersifat akrotonik dalam membentuk batang. Tanaman yang termasuk model raux pada taman kota Banyuwangi adalah glodogan tiang (Polyalthia longifolia) dan cemara kipas (Platycladus orientalis). 

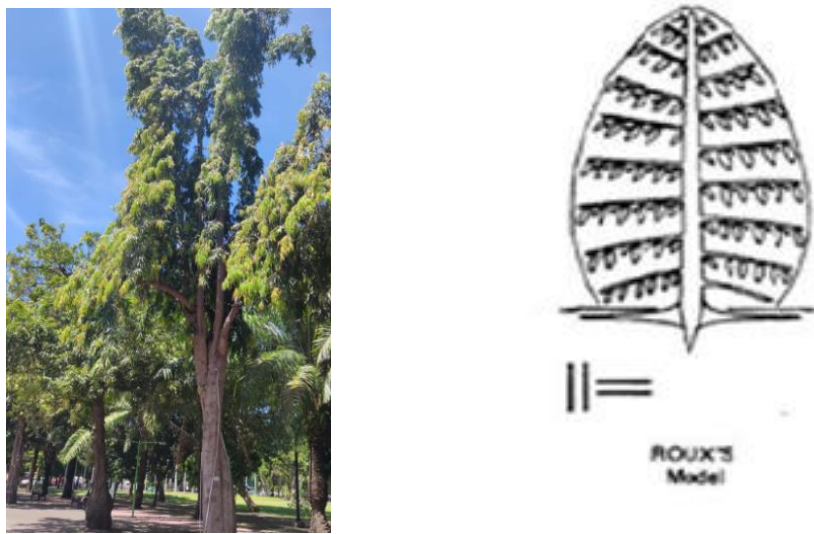

Gambar 7. Polyalthia longifolia

\section{Model Massart}

Arsitektur jenis Massart memiliki ciri batang bercabang, poliaksial, homogen. Percabangan seluruhnya bersifat acrotonic dalam membentuk batang, bukan konstruksi modular dengan perbungaan lateral, pola percabangannya umum monopodium, pertumbuhan batang dan cabang ritmik dan percabangan flagiotropik bukan karena aposisi, monopodial atau simpodial karena substitusi. Model tanaman dengan arsitektur massart di taman kota Banyuwangi adalah jambu bol (Syzygium malaccens).
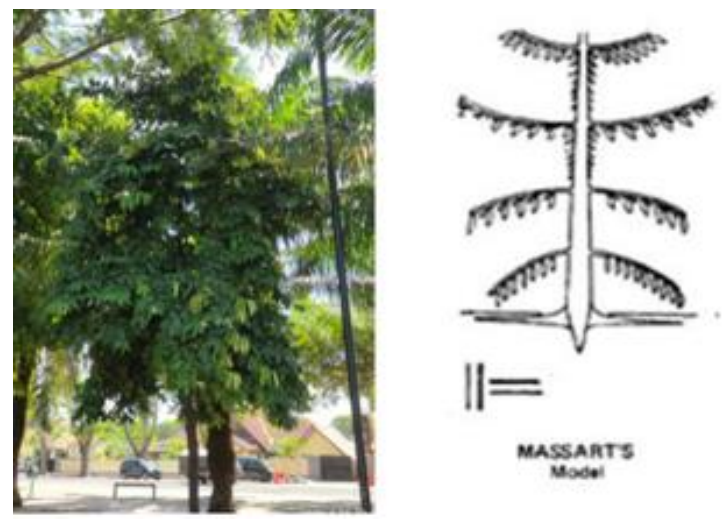

Gambar 8. Syzygium malaccense 


\section{KESIMPULAN DAN SARAN}

\subsection{Kesimpulan}

Berdasarkan hasil penelitian diperoleh data bahwa terdapat 21 spesies pohon yang digunakan sebagai peneduh. Semua jenis yang ditemukan tersebut tergabung dalam 13 Famili. Masing-masing tanaman menunjukkan model arsitektur troll, aubreville, corner, raux, massart, rauh, campagnat, kwan koribadidapatkan model arsitektur pohon di Taman Kota Banyuwangi cukup beragam. Diantara 11 jenis yang terpilih sebagai sampel, ditemukan 11 model arsitektur pohon yaitu: Troll (2 jenis), Corner ( 5 jenis), Aubreville (2 jenis), Rauh (5 jenis), Masart (1 jenis), Prevost (1 jenis), Koriba (1 jenis).

\subsection{Saran}

Perlu dilkukan penelitian mendalam tentang serapan karbon dari masingmasing model arsitektur sehingga benar dapat menjadi rujukan pemilihan pohon yang tepat untuk taman kota

\section{REFERENSI}

Ekowati G, dkk, 2017. Model Arsitektur Percabangan Beberapa Pohon di Taman Nasional Alas Purwo. Jurnal Penelitian Biotropika Vol 5 No 1. Jurusan Biologi Universitas Brawijaya. Hal 27-35

Hasanuddin. 2013. Model Arsitektur Pohon Hutan Kota Banda Aceh sebagai Penunjang Praktikum Morfologi Tumbuhan. Jurnal EduBio Tropika, Volume 1, Nomor 1, Oktober 2013, hlm. 1-60. Aceh: FKIP Universitas Syiah Kuala.

Hairiah K, Rahayu S. 2007. Pengukuran Karbon Tersimpan di Berbagai Macam Penggunaan Lahan. Buku. Bogor. World Agroforestry Centre ICRAF, SEA Regional Office, University of Brawijaya, Unibraw, Indonesia. 77p.

Krisnawati, H., Kallio, M. dan Kanninen, M. 2011 Aleurites moluccana (L.) Willd.: Ekologi, Silvikultur dan Produktivitas. CIFOR, Bogor, Indonesia. 
Handoko, P. 2007. Pendugaan simpanan karbon di atas permukaan lahan pada tegakan akasia (Acacia mangium willd.) di BKPH Parung Panjang KPH Bogor perum perhutani unit III Jawa Barat dan Banten. Skripsi. Institut Pertanian Bogor. Bogor. $30 \mathrm{p}$.

Putri AHN, dkk. 2015. Potensi Penyerapan Karbon Pada Tegakan Damar Mata Kucing (Shorea Javanica) Di Pekon Gunung Kemala Krui Lampung Barat. Jurnal Penelitian Sylva Lestari Vol 3 No. 2. Hal 13-20

Tjitrosoepomo, G. 2007. Taksonomi tumbuhan (Spermatophyta). Cetakan kesembilan. Gajah Mada University Press. Yogyakarta

Van Steenis, C.G.G.J. 2008. Flora: untuk sekolah di Indonesia. Terjemahan M. Surjowinoto, S. Hardjosuwarno, S.S. Adisewojo, Wibisono, M. Partodidjojo, S. Wirjahardja. Pradnya Paramita. Jakarta. 